\title{
Economic Nationalism and Economic Integration: The Austro-Hungarian Empire in the Late Nineteenth Century
}

\author{
Max-Stephan Schulze \\ Nikolaus Wolf
}

CESIFO WORKING PAPER No. 2813

CATEgORY 8: TRADE POLICY

OCTOBER 2009
An electronic version of the paper may be downloaded
- from the SSRN website:
- from the RePEc website:
- from the CESifo website:
www.SSRN.com
www.RePEc.org
www.CESifo-group.org/wp




\title{
Economic Nationalism and Economic Integration: The Austro-Hungarian Empire in the Late Nineteenth Century
}

\begin{abstract}
This paper seeks to reconcile two seemingly contradictory strands in the literature on economic development in the late nineteenth century Habsburg Empire - one emphasizing the centrifugal impact of rising intra-empire of nationalism, the other stressing significant improvements in market integration across the empire. We argue that the process of market integration was systematically asymmetric, shaped by intensifying intra-empire nationality conflicts. While grain markets in Austria-Hungary became overall more integrated over time, they also became systematically biased: regions with a similar ethno-linguistic composition of their population came to display significantly smaller price gaps between each other than regions with different compositions. The emergence and persistence of this differential integration cannot be explained by changes in infrastructure and transport costs, simple geographical features or asymmetric integration with neighbouring regions abroad. Instead, differential integration along ethno-linguistic lines was driven by the formation of ethnolinguistic networks. Finally, the analysis shows that the emerging pre-war regional integration patterns - shaped by nationalist sentiment - effectively anticipated the post-war settlement: the fault lines along which the Habsburg Empire was to break up eventually are evident in the price data about a quarter of a century or so before the outbreak of the First World War.
\end{abstract}

JEL Code: F15, J15, N13.

Keywords: Habsburg Empire, market integration, nationalism, networks, pre-1914 Europe.

\author{
Max-Stephan Schulze \\ London School of Economics \\ Department of Economic History \\ Houghton Street \\ UK - London WC2A $2 A E$ \\ m.s.schulze@lse.ac.uk
}

\author{
Nikolaus Wolf \\ Department of Economics \\ The University of Warwick \\ UK - Coventry, CV4 7AL \\ nikolaus.wolf@warwick.ac.uk
}

July 2009

We thank the Fritz Thyssen Foundation for project grant 'The trade network of central Europe, 1850-1939' (Az.10.05.2.050). M.S. Schulze gratefully acknowledges financial support from the ESRC (grant RES-000-22-1598). Thanks are due to Dudley Baines and Nick Crafts for helpful suggestions, to Felipe Fernandes for excellent research assistance, and to participants for their comments at seminars and conferences at Barcelona, Bruxelles Libre, Humboldt, Reading, Tübingen and Warwick universities, at EUI Florence and the London School of Economics as well as the ASSA meeting Chicago. 
At the turn of the twentieth century, the now long-defunct Habsburg Empire was among the leading powers of Europe, with a share of roughly 13 per cent in total European population and producing about 10 per cent of Europe's GDP. By the end of the First World War, the empire had militarily, politically and economically collapsed. The Treaties of St Germain (1919) and Trianon (1920) merely confirmed what had become reality from late October 1918: the Monarchy was dismembered and its territories were either incorporated into new nation states or ceded to neighbouring countries. Austria and Hungary were reduced to small landlocked countries, while Czechoslovakia, Yugoslavia and Poland emerged as independent nation states. The lands once tied together in a multinational customs and monetary union were now separated by no less than eleven national borders, quantitative and non-quantitative barriers to trade and different national currencies.

There is an extensive historiography, reaching back into the years immediately after the First World War, which examines the rise and impact of nationalism in the Habsburg Monarchy as a multinational state. ${ }^{3}$ Irrespective of different analytical perspectives, the centrifugal, disintegrative forces of intra-empire nationalism have frequently been identified as key ingredients in a Habsburg story of 'imperial decline and dissolution'. ${ }^{4}$ Yet most of this historical literature has a lot more to say on the political origins and consequences of nationality conflicts within the empire than on their economic dimensions. A more recent literature on economic nationalism, especially on the cooperative movement within the Habsburg Empire has started to explore the formation of economic institutions along

\footnotetext{
${ }^{3}$ Recent work includes Berend, History derailed; see also Rudolph and Good, eds., Nationalism and empire.

4 Jaszi, Dissolution; Kornish, 'Constitutional aspects'; Wank, 'Habsburg Empire' and 'Reflections'; Lieven, Russian Empire.
} 
ethno-linguistic lines. ${ }^{5}$ However, we still know very little about the extent to which, say, Czechs or Germans, Poles or Hungarians were conditioned in their economic behaviour by language, nationality or loyalty to their region and if behaviour along such lines changed over time. What we do know from the mainly political historiography is that over the second half of the nineteenth century, and with some variation in intensity, antagonism between different national and ethnic groups gained in importance.

In contrast, there is another branch in the historiography that rejects the notion of the empire's fall as inevitable or the Habsburg state as having become unviable. ${ }^{6}$ This seems to be supported by findings of the last thirty or so years of quantitative research into the economic development of the Habsburg Monarchy. Modern Economic Growth began to emerge in the empire's western regions in the late eighteenth century and diffused gradually to the less advanced regions. This diffusion process went hand-in-hand with a spatial widening in market integration, stimulated by improvements in infrastructure during the nineteenth century. ${ }^{7}$ Here the main message emerging is one of 'imperial stability' rather than decline. The issue then is whether and how these seemingly contradictory findings of intra-empire nationalism and intra-empire economic integration across regions can be squared.

In this paper we argue market integration proceeded asymmetrically, shaped by intensifying intra-empire nationality conflicts that, in a way, foreshadowed the dissolution of the Empire. Drawing on price evidence from grain markets, we show that overall market integration improved over time. This tallies fully with previous findings in the literature and is consistent with the evidence on

\footnotetext{
${ }^{5}$ Pogany et al., Nationale Wirtschaft; Lorenz, eds., Cooperatives in ethnic conflicts.

${ }^{6}$ E.g. Sked, Decline and fall.

7 Good, Economic rise; Komlos, Customs union, and Stature, nutrition and economic development.
} 
infrastructure improvements. ${ }^{8}$ However, such 'global' integration does not preclude the possibility that market integration evolved asymmetrically over time: some region or city pairs may have integrated relatively more than others. To explore this issue and to assess the potential quantitative significance of intra-empire nationalism therein, we examine the impact or otherwise of broadly conceived home bias within an analytical framework that is cognizant of the profound ethnic heterogeneity across the Habsburg domains and informed by the recent literature on the trade creating and trade diverting effects of social and ethnic networks. Our analysis suggests that over time market integration became systematically biased: regions with a similar ethno-linguistic composition of the population displayed significantly smaller price gaps between each other than regions with different compositions. The emergence and persistence of such differential integration cannot be explained by changes in infrastructure and transport costs, simple geographical features, asymmetric integration with neighbouring regions abroad, or by difficulties of communication between language groups. Instead, the evidence shows that the observed asymmetries in market integration were related to the effects of ethno-linguistic networks. Finally, the emerging pre-war regional integration patterns - shaped by nationalist sentiment - effectively anticipated the post-war settlement: the fault lines along which the Habsburg Empire was to break up eventually are evident in the price data about a quarter of a century or so before the outbreak of the First World War. We conclude that intensifying intra-empire nationality conflicts led to severely asymmetric patterns of market integration - economic nationalism mattered.

\footnotetext{
${ }^{8}$ Good, Economic rise.
} 
The rest of the paper is organized as follows. Section I briefly sketches out key issues in the historiography on the significance of nationality conflicts in Habsburg economic development since 1867. Section II explains our empirical approach to assess the effects of intra-empire nationalism on market integration and outlines our new dataset on prices, infrastructure, freight rates and measures of ethno-linguistic heterogeneity across the empire. Section III presents the results of estimating the impact of ethno-linguistic networks on inter-regional price gaps. Section IV includes several robustness checks on the finding that asymmetric patterns of market integration were driven by the effects of nationalism as distinct from communication effects. Section $V$ explores briefly the extent to which the thrust of pre-war intra-empire economic nationalism is reflected in the post-war boundaries of the Habsburg successor states. The concluding section summarizes the main findings and looks to some wider implications.

\section{I}

The ultimate causes of Austria-Hungary's dissolution are still heavily disputed in the historical literature. However, nationalism features as a key variable in most approaches, irrespective of whether they adopt a structuralist perspective on imperial decline ${ }^{9}$, point to the failure of political elites at the centre to engineer reform and maintain legitimacy ${ }^{10}$ or focus on the uncompromising pursuit of, effectively, mutually exclusive political aims by the different national communities in the crownlands ${ }^{11}$. In short, historians have since long argued that the rise of national self-consciousness and growing

\footnotetext{
9 Wank, 'Habsburg Empire', and 'Reflections'.

10 Jaszi, Dissolution; Taylor, Hapsburg Monarchy.

${ }^{11}$ Kornish, 'Constitutional aspects'; Lieven, Russian Empire.
} 
conflict among the empire's various 'nationalities', and the failure of the 1867 Constitutional Settlement between Austria and Hungary to offer an institutional arrangement capable of diffusing this conflict, were major factors in the empire's decline. In that view, the First World War was the final blow in a long process of dissolution. Linked to this perspective is the notion that inter-regional inequality and intensifying intra-empire economic nationalism undermined the coherence and performance of the Habsburg economy which, ultimately, only served to accelerate the empire's demise in a war it was not economically fit to fight. Oszkár Jászi in his classic Dissolution of the Habsburg Monarchy (1929) put this case most dramatically when he wrote that, 'by 1913, the Austro-Hungarian Monarchy was already a defeated empire from the economic point of view'.

However, there is also a dissenting historiography. It was losing the war that finished off the empire, but not any insurmountable structural, political or economic problems in the preceding decades making for inevitable decline and dissolution. ${ }^{12}$ Interpretations along these line are broadly in tune with the findings of quantitative research on the economic history of the Habsburg Monarchy. These make for a less damning assessment of Austria-Hungary's economic performance than earlier writing in the field. ${ }^{13}$ Even though economic growth and structural change in the empire were not nearly rapid enough to catch-up with the European leaders before the war ${ }^{14}$, the work of, in particular, David Good and John Komlos has shown that the origins of Kuznetsian Modern Economic Growth in the western regions of the empire reach back into the eighteenth century, that growth impulses began to diffuse gradually from the more developed

\footnotetext{
12 Sked, Decline and fall.

${ }^{13}$ For example, Gerschenkron, Economic backwardness.

${ }^{14}$ Schulze, 'Patterns of growth', and 'Origins of catch-up failure'.
} 
western to the less advanced eastern and south-eastern regions and that broad intra-empire market integration across the crownlands made significant progress up to $1914 .{ }^{15}$ The fact that the empire lost the Great War and that economic factors played a major role in this tells us that the war it came to fight was of a scale too large to sustain on the basis of the resources at its disposal. ${ }^{16}$ It does not necessarily imply that Austria-Hungary's economy was too underdeveloped to maintain the empire's territorial integrity in peacetime (or, for that matter, in times of wars that made less demands on human and material resources).

Bruckmüller and Sandgruber observe an apparent contradiction between, on the one hand, increasing inter-regional economic integration within the empire over the $19^{\text {th }}$ century and, on the other, the simultaneous rise of nationalist movements 'based mainly on common language or national consciousness (...) [that] strongly ran counter to the collective consciousness of belonging to a common state'. ${ }^{17}$ Yet the historical evidence on the impact of nationalism on the empire's economy is patchy and ambiguous. For instance, at governmental level, the post-1867 empire had an inbuilt potential break-line: the customs union between Austria and Hungary had to be renegotiated every ten years (and approved by both parliaments) and so had the so-called 'quota'. Common affairs (largely the army) were paid for out of tariff revenue and the quota was the proportion each part had to contribute to make up for any shortfall in tariff revenue. ${ }^{18}$ Berend and Ránki argue that by the turn of the century the question of an independent Hungarian customs area had nearly

\footnotetext{
${ }^{15}$ Good, Economic Rise; Komlos, Customs union, and Stature, nutrition and economic development.

${ }^{16}$ Schulze, 'Austria-Hungary's economy'.

17 Bruckmüller and Sandgruber, 'Concepts of economic integration', p. 159.

${ }^{18}$ Eddie, 'Economic policy', p. 815, and 'Common expenditures', pp. 360-2.
} 
become the dominant issue in Hungarian politics. ${ }^{19}$ However, they emphasize that this was so primarily for political and nationalist reasons rather than on economic grounds. In the end, and despite the political deadlock in Austria's parliamentary process since 1897 that grew out of intensifying nationality conflict, the customs union continued to be renewed, if need be by imperial decree. 'The fact that the Hungarians did not take advantage of this situation [i.e. the political stalemate in the Austrian half of the empire] shows the importance of the Austrian market for Hungarian agricultural producers'. ${ }^{20}$

While the core political and economic interests of the Germans and the Magyars as the dominant groups in the two halves of the empire (without either of them having an absolute population majority in Austria and Hungary) were recognized and broadly accommodated in the constitutional compromise of 1867 that established the Dual Monarchy, those of the Slavic people in both parts of the empire were not. There is evidence going beyond the mere observation of increasingly pervasive nationalism within the empire that suggests deepening social and economic separation between self-integrating national communities in the decades following the Ausgleich ${ }^{21}$, Jaworski's research on boycott movements between different ethnic groups within the multi-national setting of East Central Europe points to ethnic mobilization as a key element of intra-state economic nationalism at work ${ }^{22}$. Nationalist élites sought to mobilize popular political support for the national cause and to advance the economic interests of their clientele. In a similar vein, the contributions in Lorenz' edited volume map the growing interrelatedness of national movements and the cooperative movement in

\footnotetext{
${ }^{19}$ Berend and Ránki, 'Economic factors'.

${ }^{20}$ Bruckmüller and Sandgruber, 'Concepts of economic integration', p. 161.

${ }^{21}$ Ibid.

22 Jaworski, 'Zwischen ökonomischer Interessenvertretung'.
} 
East Central Europe. ${ }^{23}$ Whilst, initially, recruitment was based largely on professional criteria, over the course of the late nineteenth century cooperatives became increasingly organized along ethnic lines. 'Through national segregation on the regional, and, increasingly, on the local level, cooperatives evolved from socially organized and a-national, into inter-societal, nationally organized institutions ${ }^{\prime 24}$ during a phase of 'ethnic segregation' (broadly, in the 1860 s and '70s). This was followed by a phase of 'ethnic mobilization', much in line with intensifying national conflicts, when cooperation became an economic mass movement. A key issue here is the drive towards price discrimination through the concentration of selling and purchasing power and as a means to strengthen the 'national economy'. The theme of ethnically-based economic 'selfintegration' as part of Czech national revival features also prominently in Albrecht's study of rural banks and Czech nationalism in Bohemia in the second half of the $19^{\text {th }}$ century. ${ }^{25}$

However, the extent of these phenomena and their overall quantitative significance within the broader context of Habsburg economic development and their potential role in the empire's eventual dissolution remain problems unresolved ${ }^{26}$. The remainder of this paper offers the first quantitative assessment of the impact of intra-empire nationalism on product market integration across the empire.

\footnotetext{
23 Lorenz, ed., Cooperatives in ethnic conflicts. See, in particular, the chapters by Hunyadi on Transylvania, Struve on Galicia and Lazarvić on Slovenia.

24 Ibid., p.22

25 Albrecht, 'Rural banks'.

${ }^{26}$ Eddie, 'Economic policy', pp. 814-22; Bruckmüller and Sandgruber, 'Concepts of economic integration', p. 160.
} 


\section{I}

Our central hypothesis is that the intensification of intra-empire economic nationalism led to asymmetric integration of regional markets within an overall integrating Habsburg economy. To this end we examine the dynamics of market prices across the empire and over time: ceteris paribus, two cities with little or no ethno-linguistic differences are likely to trade more with each other than cities with larger differences, given that trade networks tend to evolve along social and ethnic contacts ${ }^{27}$. According to Rauch and Trindade ${ }^{28}$, ethnic networks may promote trade either by providing market information or by providing community enforcement of sanctions, for example by blacklisting traders who violate specific rules of the community. In the first case their effects on trade should be larger for trade in differentiated products (for example machinery) than for trade in homogeneous products, especially those with 'reference prices' such as grain ${ }^{29}$. In contrast, in the latter case, which has been highlighted by Greif and by Rauch and Trindade, community sanctions should affect trade independently of the characteristics of the traded goods. ${ }^{30}$ This network literature speaks to the Habsburg case of profound ethnic heterogeneity and the increasingly selfintegrating national communities identified in the historiography and provides the theoretical background to this study of grain price dynamics.

In line with many other studies ${ }^{31}$, we take non-random, systematic deviations from the law of one price as indicators for trade costs. Further, we assume that trade costs can be split up into three

\footnotetext{
${ }^{27}$ Greif, 'Contract Enforceability'; Rauch and Trindade, 'Ethnic Chinese networks'.

${ }^{28}$ Rauch and Trindade, 'Ethnic Chinese networks'.

${ }^{29}$ Rauch, 'Business and Social Networks'.

${ }^{30}$ Greif, 'Contract Enforceability'; Rauch and Trindade, 'Ethnic Chinese networks'.

${ }^{31}$ E.g. Engel and Rogers, 'How wide is the border?'; Shiue, 'Political fragmentation'; and Trenkler and Wolf, 'Integration across borders'.
} 
components: trade costs that depend on distance (transport costs), trade costs that depend on networks (or related trade creating factors), and all causes of trade costs that are location-specific but not specific to any pair of locations ${ }^{32}$. If both distance-related and location-specific trade costs decrease over time, while the strength of networks stays high or even rises, the relative impact of the latter on trade will increase, which might result in patterns of asymmetric integration shaped by network boundaries and intensities.

The relationship between price dynamics and trade costs is examined within a simple analytical framework. Consider two cities $i$ and $j$, letting $P_{i, t}$ and $P_{j, t}$ denote the respective prices of the good in cities $i$ and $j$. Let $\left(p_{i t}-p_{j t}\right)=$ gap $p_{i j t}$ denote the percentage gap for the two prices at time $t^{33}$. Assume further that the trade costs are proportional to the prices in the importing market place. In line with the recent economic geography literature let $\left(1-\mathrm{e}^{-\mathrm{T}}\right) \mathrm{P}_{\mathrm{i}, \mathrm{t}}$ be the trade costs, where $T>0$ is a cost parameter. Then, $e^{-T} P_{i, t}$ is the per-unit revenue when the good is sold in city $\mathrm{i}$. Intuitively, $\mathrm{T}$ depends positively on the geographical distance between the cities $i$ and $j$. Moreover, when network effects are present, $\mathrm{T}$ also differs depending on whether or not the city populations are part of the same network. Finally, trade from $j$ to $i$ is only profitable if $P_{i, t} e^{-\tau}>P_{j, t}$. This results in the condition: $\log \left(P_{i, t} / P_{j, t}\right)=\operatorname{gap}_{i j, t}>T$. Hence, arbitrage from $j$ to $i$ takes place when the percentage price gap is larger than the cost parameter $\mathrm{T}$. Equivalently, one trades from city $\mathrm{i}$ to $\mathrm{j}$ only if $\mathrm{gap}_{\mathrm{ij}, \mathrm{t}}<$ $-\mathrm{T}$. Thus, we obtain $[-\mathrm{T} ; \mathrm{T}]$ as a band of no-arbitrage. Within this band, no trade occurs that could reduce price differences between the two markets because trade costs exceed possible arbitrage profits. Obviously, the size of this band increases with $T$, which in turn will

\footnotetext{
32 This is similar to the idea of multilateral resistance in Anderson and van Wincoop, 'Gravity with gravitas'.

${ }^{33}$ Shiue, 'Political fragmentation'.
} 
depend on several factors such as transport costs. In the literature, this trade cost view is often referred to as a weak form of the law of one price. ${ }^{34}$

The quantitative analysis builds on four new data sets: grain prices, railway distances, railway freight rates and language statistics. The main characteristics of the data are set out below.

Grain Prices. We use annual current wholesale prices for five types of grain (wheat, rye, barley, oats, corn) in twenty major cities of the empire to examine the integration of the Habsburg economy over the period 1878-1910. ${ }^{35}$ Grain prices are given in the original sources in the same currency for all cities but sometimes for different volume or weight measures. All prices have been converted into Austrian Heller per 100 kilograms to make them fully comparable both in the crosssection and over time. The price data are employed to construct our dependent variable, i.e. the log-ratio of grain prices in two cities $i$ and $\mathrm{j}$ for each year and all of the 190 city-pairs ij.

Map 1 shows the regional spread of the sample cities across the empire and the Habsburg successor states they came to belong to after 1918:

(a) Vienna (Lower Austria), Linz (Upper Austria), Graz (Styria) and Innsbruck (Tyrol) which became part of the postwar Austrian Republic;

(b) Prague in Bohemia, later becoming the capital of Czechoslovakia ;

(c) Cracow and Lemberg in Galicia, both cities became part of the post-war Polish state;

\footnotetext{
${ }^{34}$ This is equivalent to the so-called spatial arbitrage condition if it is only required that prices of the same good at two cities differ at most by the trade costs; see, for example, Fackler and Goodwin, 'Spatial price analysis'.

35 The main sources for the price data are SJB and ÖSH, augmented by Pribram Materialien zur Geschichte (on Vienna), Hoszowoski, 'Ceny we Iwowie w latach' (on Lemberg), Gorkiewicz, 'Ceny w Krakowie w latach' (on Cracow), Preisstatistik and MSE on Budapest and the other cities in Hungary.
} 
(d) Czernowitz in the Bukowina which was ceded to Romania after the First World War;

(e) Trieste, in the Littoral, became part of Italy;

(f) Budapest, the centre of Hungary in both its pre- and postwar borders;

(g) Bratislava (Pozsony) in the Danube Left Bank district, later becoming part of Czechoslovakia;

(h) Pecs and Sopron in the Danube Right Bank district, part of both pre- and post-war Hungary, as was

(i) Szeged in the central Danube-Theiss Basin;

(j) Kassa on the right bank of the Theiss river, the area was ceded to Czechoslovakia after the First World War;

(k) Debreczen and Nagy Varad in the expansive Theiss Left Bank district; the predominantly Romanian parts of the region, where Nagy Varad was located, were later ceded to Romania along with

(I) Arad and Temesvar in the Theiss-Maros Basin, and

(m) Kolozsvar in Transylvania.

The cities listed under (a) to (e) were part of the Austrian half of the empire (Cisleithania), those under $(\mathrm{f})$ to $(\mathrm{g})$ belonged to the Kingdom of Hungary (Transleithania).

[Map 1 about here]

Railway Distances. The independent variables include, first, the shortest railway connection between all 190 city-pairs $\mathrm{ij}$, again for each year 1878-1910. By 1878, all cities in the sample had been connected to the railway network. However, over time and up to the First World War, Austria-Hungary's railway network became denser and many bilateral distances shorter. This is fully accounted for in the 
time-varying railway distance measures derived here from a wide range of sources. ${ }^{36}$

Railway Freight Rates. The distance measures are augmented by new, fully time-varying estimates of railway freight rates for grain that account for both terminal and variable (i.e. distance-related) rate components ${ }^{37}$. Used in conjunction with railway distances, they allow for the reconstruction of the costs of transport between two cities $i$ and $j$ as an alternative independent variable. The estimates of railway transport cost are based on material from a diverse set of sources. The (US) Bureau of Railway Economics (1915) provides comparative 1914 freight rate data for a large number of different-length railway routes in different countries and for a variety of products. Decomposing into terminal and variable charges, we obtain a 1914 baseline estimate for Austria-Hungary. Noyes provides average railway freight rates per ton-mile for Austria-Hungary (and several other countries). ${ }^{38}$ This information has been converted into indices and used to extrapolate back to 1870 both the terminal and variable components in the 1914 equations for Austria-Hungary. In addition to the impact of changes in freight rates over time, the effect of using transport cost so computed as compared to the proxy of simple railway distances is quite straightforward: given a common terminal component, average transport costs per kilometre decline in distance. Figure 1 illustrates the combined effect of falling freight rates and shortening distances over the course of the late nineteenth century. The greatest gains in terms of declining freight costs were made over the longest distances, here exemplified by the Innsbruck-Czernowitz connection.

\footnotetext{
${ }^{36}$ See the sources listed under Railway Distances (1878-1913).

37 Schulze, 'Regional Income Dispersion'.

${ }^{38}$ Noyes, American Railroad Rates.
} 
[Figure 1 about here]

Languages. For each of the twenty cities we reconstruct the composition of its population by language, taking account of the nine major languages spoken across the empire. We use 'main language spoken' (Austrian cities) and 'mother tongue' (Hungarian cities) as proxies for urban populations' ethnicity. ${ }^{39}$ Table 1 reports population composition by language and shows the extent of ethno-linguistic heterogeneity both within and across the twenty cities in the sample. The data, extracted from the official (decadal) censuses, refer to the population within the boundaries of a city and that of the immediately adjacent or surrounding administrative district(s). Given the widening over time of the geographical and administrative boundaries of some of the cities (especially, Budapest, Prague and Vienna), this makes for more stable and meaningful 'catchment areas'. The most striking feature here is the pronounced heterogeneity across the cities and, in some cases, the shifts in population shares held by the different national groups. We use the language data to construct a bilateral measure of ethno-linguistic similarity (or 'matching probability') of the two cities in any one of the 190 city-pairs as an independent variable. Section IV below offers robustness checks on this variable's explanatory power.

[Table 1 about here]

How did grain prices in Austria-Hungary evolve over time? Figure 2 shows the cross-section average prices of the five grains for

39 The 1880-1910 censuses report only languages spoken, not nationality or ethnicity. A comparison of the Austrian 1880 language data with the 1857 census data on nationality indicates a very close match, even if allowance is made for inter-temporal shifts in the composition. See Horch, 'Language and identity' on the relationship between language and national identity in the Habsburg context. 
1878-1910. Prices tended to decline until the mid-1880s, then fluctuated without a visible trend for about twenty years, before they moved upwards in the decade prior to the First World War. Not surprisingly, wheat prices were markedly above other grain prices, typically followed by rye and barley.

[Figure 2 about here]

Figure 3 plots the 'global' or 'between' coefficient of variation over the whole cross-section of the twenty cities averaged over wheat, rye, barley, oats, and corn, 1878-1910 (solid line). The variation of grain prices across cities declined substantially over time, in line with previous findings of $\mathrm{Good}^{40}$. However, it is possible that integration proceeded asymmetrically, that is some city pairs may have integrated relatively more than others. As a first check, Figure 3 also shows the coefficients of variation (calculated again as an average over the five grains) within groups of cities that after 1918 belonged to the same Habsburg successor state. Finally, the graph shows the percentage difference between the 'between' and 'within' price dispersion over time, with the latter calculated as the mean of 'within group' variations (grey line).

[Figure 3 about here]

The evidence so far suggests that, first, city-pairs with a common post-war border were apparently already in 1878 somewhat better integrated than other pairs, which can be explained partly in terms of their different average distances. Second, price dispersion declined with some fluctuation within all 'national' city groups along similar

${ }^{40}$ Good, Economic rise. 
paths. But, third, the percentage gap between 'global' and 'within' price dispersion was increasing during 1878-1910, from about 30 per cent to more than 50 per cent: integration became progressively asymmetric over the late nineteenth century.

To explore such asymmetric integration and its origins systematically, we examine a balanced panel of price ratios between all 190 possible city-pairs in our sample, drawing on a total pool of more than 10,000 observations. The analysis of the price dynamics in this panel has to take into account that trade costs imply a noarbitrage band in relative prices and hence non-linearities. Moreover, we need to focus on the cross-section, whilst allowing for productand city-specific factors and - crucially - allowing for structural change over time. The basic idea is that on average, higher trade costs should limit the scope for arbitrage and hence increase the price gap between any pair of cities. Trade costs, in turn, can be decomposed and we distinguish three categories: trade costs that depend on distance (transportation costs), cost components related to networks, and trade costs that are city-specific. We estimate the following simple specification:

$\log \left(\frac{p_{i, t}^{h}}{p_{j, t}^{h}}\right)=c_{0}+c_{1} * \log \left(\right.$ raildistan $\left.^{h} e_{\mathrm{ij}, \mathrm{t}}\right)+c_{2}{ }^{*}$ language ${ }_{\mathrm{ij}, \mathrm{t}}+\sum_{\mathrm{g}=1}^{20} c_{g} c i t y_{g}+\varepsilon_{i j, t}^{k}$

where raildistance is the railway distance between two cities $i$ and $j$ in kilometres, language is a bilateral measure of ethno-linguistic similarity between city populations, city is a full set of dummies over all cities $\mathrm{g}$ to capture unobservable city-specific factors, while $\varepsilon_{i j, t}^{k}$ is an i.i.d. error component. The index $\mathrm{h}$ stands for the five kinds of grain in our sample. The variable language is calculated as

$$
\text { language }_{i j, t}=\sum_{k=1}^{n}\left(a_{i, t}^{k} * a_{j, t}^{k}\right)
$$


where $a_{i, t}^{k}$ is the percentage share of language $\mathrm{k}$ in city $\mathrm{i}$ and at time $\mathrm{t}$, and $n$ is the total number of language groups (in our case $n=9$ ). This is equivalent to summing up over all possible same language encounters between individuals from the two different cities in each pair and dividing by the total number of all possible encounters for that city-pair. ${ }^{41}$

This 'matching probability' varies between 0 (no similarity between two cities $i$ and $j$ ) and 1 (no differences). For example, for 1910 the lowest score is 0.0003 for the city-pair Lemberg-Debreczen, the highest is 0.9864 for Graz-Linz. Note that, similar to Rauch and Trindade, we use language as a proxy for membership in a specific ethno-linguistic network, say Czech or Hungarian, rather than as a control for the costs of communication. ${ }^{42}$ We explore the crucial differences in Section IV below.

\section{I}

To assess the evidence of asymmetric integration across the Habsburg regions, we estimate equation (1) using a generalised least squares estimator, which allows for heteroskedastictity in the crosssection. We start by pooling over all five grains and over the whole period 1878-1910. Reported standard errors are based on White's period robust coefficient variance estimator throughout, to accommodate for serial correlation in the price data. Table 2, column 1 , shows the results.

\footnotetext{
41 The underlying absolute figures are truncated to facilitate a full match of the Austrian and Hungarian language groups. The very small group of 'other languages' (i.e. those different from the nine main languages referred to in Table 1), which is not reported for Austrian cities and for Hungary available only for 1910, is excluded.

42 Rauch and Trindade, 'Ethnic Chinese networks'.
} 
[Table 2 about here]

As hypothesized, we find that, whilst controlling for unobservable city-specific effects, price differentials increased significantly in distance between the cities and decreased in the ethno-linguistic match between their populations. The coefficient on language is negative (i.e. the larger ethnic congruency between cities, the smaller the price gap) and highly significant, which here is interpreted as evidence of trade costs related to ethnic networks.

This finding is robust to the theoretically and empirically preferable use of time-varying transport costs instead of railway distances. We re-estimate equation (1), replacing raildistance by freightcost, a measure that fully accounts for inter-temporal changes in both distances (due to the extension of the railway network over time) and freight rates. Table 2, column 2, gives the results. While measuring transport costs properly makes some difference (the relevant coefficient is now smaller than before), the results are materially unchanged. Note that in both cases language is estimated to be highly significant after controlling for distance or transport costs. The variation in our sample is sufficiently high to distinguish between bilateral price differences related to distance and bilateral price differences related to network effects. While, in general, very distant cities also tended to be characterized by different ethnolinguistic profiles of their populations, our sample has a lot of variation in this respect. Consider the following examples. In 1910, there were only 58 railway kilometres lying between Arad and Temesvar in Hungary, the shortest bilateral distance in our sample and about one ninth the median distance. This contrasts with the 1,515 kilometres between the two cities furthest apart - Innsbruck in the west of Austria and Czernowitz on its eastern periphery. However, 
despite these stark differences in bilateral distances, the two city pairs were characterized by virtually identical bilateral matching probabilities of .28 to .29. Further, the two cities least similar in terms of their ethno-linguistic composition, Lemberg and Debreczen, were only 432 kilometres apart - far less than the median distance of 538 kilometres.

The observed price differentials cannot be explained by major systematic administrative barriers to trade like tariffs or different currency regimes since such barriers were not in place in the Habsburg customs and monetary union. Whatever minor and, effectively, unobservable impediments to inter-regional trade there were, these are likely picked up in the location dummies. What needs accounting for is the significant impact of ethno-linguistic networks which is evident despite controlling for transport costs and locationspecific factors. A key to the nature of network-driven asymmetric integration may lie in changing patterns over time. There is no a priori reason to assume that such network effects were present over the whole period. On the contrary, the political historiography stresses the rise in intra-empire national conflict from the late 1880s and, for instance, the political deadlock between Czechs and Germans from the early $1890 s^{43}$, while recent research on intra-state economic nationalism emphasizes the growing significance of ethnic mobilization and antagonism during the $1890 \mathrm{~s}^{44}$. If the historical literature is about right on the intensification of national conflict in Austria-Hungary, we would expect our proxy for ethnic network membership (language) to be far more powerful in explaining persistent price differentials after, say, the early 1890s than before. To explore the issue systematically,

\footnotetext{
${ }^{43}$ See Berend History derailed; Kornish, 'Constitutional aspects'; and Sked, Decline and fall.

${ }^{44}$ Bruckmüller and Sandgruber, 'Concepts of economic integration'; Jaworski, 'Zwischen ökonomischer Interessenvertretung'; and Lorenz, ed., Cooperatives in Ethnic Conflicts.
} 
we extend model (1) and estimate equation (3), using fully timevarying freightcost as an independent variable and allowing the coefficient on the network measure (language) to vary between two major periods - 1878-1894 and 1895-1910:

$$
\log \left(\frac{p_{i, t}^{h}}{p_{j, t}^{h}}\right)=c 0+D_{1}+c 1^{*} \log \left(\text { freightcost }_{\mathrm{ij \textrm {j }}, \mathrm{t}}\right)+\sum_{t=1878 / 1894}^{t=1895 / 1910} c_{t} * \text { language }_{\mathrm{ij}, \mathrm{t}}+\sum_{\mathrm{g}=1}^{20} c_{g} * \text { city }_{g}+\varepsilon_{i j, t}^{k}
$$

where $D_{1}$ is an intercept dummy for $1895-1910$. The results are set out in Table 3, column 1.

[Table 3 about here]

While the estimated coefficient on freightcost remains positive and significant as expected, the negative coefficient on language is small and statistically insignificant for the period 1878-94, but much larger and statistically highly significant for the years after 1895 . This result would suggest that ethno-linguistic networks exercised no material influence on the pattern of market integration in the $1870 \mathrm{~s}$ and 1880 s, but did so in the 1890 s and early 1900 s. This quantitative finding thus ties in well with the qualitative historiography that emphasizes the growth and prevalence of antagonism between different nationalities in the last two decades or so prior to the First World War.

Note that features of natural geography such as mountains, rivers, or access to seaports cannot possibly account for the observed changes over time due to their time-invariant nature. ${ }^{45}$ However, what might have influenced the pattern of relative integration across

45 For example, the potential significance of waterborne transport along the Danube, say between Vienna, Bratislava and Budapest, is taken into account through the use of city dummies. 
Austria-Hungary is changing integration or disintegration with neighbouring regions in other countries. For example, the large changes in German and Russian tariffs 1878-1910 might have affected different regions of the Habsburg economy in different ways. We can take this into account by adding to model (3) a set of timevarying city effects, to capture city-specific integration or disintegration shocks. Table 3, column 2, shows that the introduction of time-specific city-effects does not alter the results.

It is straightforward to show that the effect exercised by ethnolinguistic networks on the pattern of market integration in the two decades prior to the Great War was considerable. A one-standard deviation decrease in matching probability implied ceteris paribus a stronger increase in (log) grain price-spreads than a one standard deviation increase in (log) freight costs. Put differently, the estimated effect of halving the matching probability would have increased the (log) grain price-spreads by $27 \%$ as compared to an increase of roughly $9 \%$ in response to doubling the average (log) freight costs. ${ }^{46}$

We conclude that city- and time-specific differences in integration - such as varying degrees of integration with neighbouring regions - cannot explain the observed asymmetric integration within the Habsburg economy. However, the extent of ethno-linguistic congruence between locations, measured as a matching probability, is a factor that can.

\footnotetext{
${ }^{46}$ To see this, define the probability of non-matching as (1-language), which essentially only inverts the sign of the estimated coefficients. A doubling of this variable will on average have the effect of $(-1) * 2 * 0.1492=0.2984$ (see table 3, column 2). This translates into a $25 \%$ increase in the average log-price-spread as compared to a $2 * 0.0486=0.0978$ or a $8.9 \%$ increase in response to doubling average (log) freight costs.
} 


\section{IV}

The argument here is that language statistics can capture membership in ethno-linguistic networks, which in turn help explain the emerging pattern of asymmetric integration within the late nineteenth century Habsburg economy. However, for this argument to hold, one needs to be able to distinguish between 'community effects' and 'communication effects' of membership in an ethnolinguistic network. Networks can provide market information, which should be facilitated by the ability to speak a common or at least a very similar language. ${ }^{47}$ They can also provide community enforcement of sanctions, for example, by blacklisting traders who violate community rules. In the first case, one would expect significant network effects on trade in differentiated products and far less so on trade in homogeneous products like wheat or rye. In the second case, however, community sanctions are seen as affecting trade independently of the characteristics of the traded goods. ${ }^{48}$ It should not matter whether it is trade in grain or trade in machinery or textiles. Since the focus here is on grain markets only, it is the second effect that likely matters most in our case. Following Dyen et al. and using the lexicostatistical similarities between languages, the 'matching probability' is extended to permit the identification of 'communication effects' as distinct from 'community effects'. 49

$$
\operatorname{DyenComm}_{i j, t}=\sum_{l=1}^{n} \sum_{k=1}^{n}\left(a_{i, t}^{k} * a_{j, t}^{l} * S W 200^{k l}\right)
$$

where SW200 is the index of lexicostatistical similarity between languages $\mathrm{k}$ and I based on the Swadesh-200 list of basic words as

\footnotetext{
${ }^{47}$ Rauch and Trindade, 'Ethnic Chinese networks'.

${ }^{48}$ Greif, 'Contract enforceability'; Rauch and Trindade, 'Ethnic Chinese networks'.

49 Dyen, Kruskal and Black, 'Indo-European Classification'.
} 
used in Dyen et al. ${ }^{50}$ For example, the SW200 index is 0.660 for Romanian and Italian, 0.223 for Romanian and Czech, 0.249 for Romanian and German, 0.766 for Czech and Polish, and 0.259 for Czech and German. The new DyenComm index then measures the probability that any two citizens from, say, Lemberg and Arad meeting can actually communicate without necessarily sharing the same mother tongue. The point of the exercise is to use the available language data via (4) in such manner that they capture the communication effects rather than the effects of membership in a specific community. In light of our hypothesis that it is community effects that drive the findings on grain price dispersion, we expect adding the communication index (4) as a control to have little effect on the results. Table 4, column 1, confirms this. The coefficient on the communications variable is either insignificant or of the wrong sign while the network effects captured in the matching probability (language) remain large and significant for the post-1894 period as before. Hence the evidence suggests that it was not communication as such that was the problem but rather growing conflict between distinct ethno-linguistic groups. Asymmetric integration was an outcome of intra-empire economic nationalism.

[Table 4 about here]

However, one cannot exclude the possibility that this result of powerful community effects may be driven by the specific metric of a 'matching probability' used here. To deal with this issue we can define

\footnotetext{
${ }^{50}$ Hungarian is not part of the Indo-European language family. We therefore set the index to zero for all pair-wise combinations with Hungarian, which tends to understate the ability to communicate between city populations. Similarly, we neglect the fact that many people will have been able to speak more than one language. This again leads us to underestimate the ability to communicate between city populations.
} 
an alternative bilateral index of ethno-linguistic heterogeneity that is similar to a Herfindahl-index:

$$
\operatorname{HFLang}_{i j, t}=1 / 2 \sum_{k=1}^{n}\left(a_{i, t}^{k}-a_{j, t}^{k}\right)^{2}
$$

If both cities have an identical ethno-linguistic composition the index equals zero. If there is no overlap in the ethno-linguistic composition, the index equals one as its maximum. Like the initial matching probability, it varies between 0 and 1 and so reflects the idea that trade costs between a pair of cities are expected to increase in the ethno-linguistic heterogeneity between them. ${ }^{51}$ As shown in Table 4, column 2 , the results remain unchanged compared to column 1 . Thus the finding of strong community effects is robust to alternative measures of ethno-linguistic networks.

\section{V}

Ethno-linguistic networks made for severely asymmetric market integration in the late nineteenth century Habsburg Empire. One way to show how this finding matters, and to shed light on its broader historical implications, is to explore the predictive power of pre-war intra-empire economic nationalism for the formation of the post-war boundaries between the Habsburg successor states. We consider the probability that any two cities in the sample would be separated by a border after 1918, given the observed changes in price spreads between cities during 1878-1910. While, again, distinguishing between the two major periods 1878-94 and 1895-1910, the approach involves estimating whether the change in the average

\footnotetext{
${ }^{51}$ Note the different expected signs on the coefficients for the matching probability and the Herfindahl measure.
} 
price spread (i.e. log price-ratio) between the two periods can predict city pairs' future separation by a border, controlling for inter-temporal changes in transportation cost. The rationale is quite straightforward: all the evidence so far suggests that growing economic nationalism is visible in a widening spread in grain prices when distance-related trade costs are properly controlled for.

Using Binary Probit, we construct a dependent variable border ${ }_{i j}$ which takes the value of 1 if cities $i$ and $j$ were separated by a border after the First World War and 0 otherwise. The independent variable spreadchange $_{\mathrm{ij}}$ is the change in the (period) average price spread, standardized by (period) average transportation cost, between cities $i$ and $\mathrm{j}$. The relevant averages are computed over the two respective periods 1878-94 and 1895-1910. The results are reported in Table 5 where column 1 refers to just two grains (wheat and rye) for which price data are available for all years and locations; column 2 refers to all five grains where the number of observations is smaller due to missing price data for some grains and city pairs.

[Table 5 about here]

In both cases, the coefficient on spreadchange is highly significant: the larger the change in bilateral price differentials over time, which is unexplained by a change in transport costs (or distance-related trade costs), the higher the probability of a post1918 border between two cities. This finding is far from trivial. Common sense would suggest that the probability of any two cities to be separated by a border after the war should increase in their geographical distance and distance-related trade costs. The new evidence presented here shows that after controlling for this, the pattern of price dynamics helps predicting the future political borders. If it was economic nationalism that drove asymmetric integration 
(and widening relative price differentials) in the pre-war period, then it is not too far fetched to hypothesize that it was pre-war economic nationalism that, effectively, shaped the lines along which the empire broke-up of in the wake of the First World War.

\section{VI}

In this paper we argue that two seemingly contradictory strands in the literature - one emphasizing the centrifugal impact of growing intra-empire nationalism, the other stressing significant improvements in market integration across the empire - can be reconciled. The process of overall market integration across the Habsburg domains, though ongoing, was profoundly asymmetric: some localities were more rapidly and deeply integrating with each other than others - and 'national biases' played a key role in that. Empire-wide absolute declines in price differentials between regions or towns went thus hand-in-hand with profound regional differentials in relative integration (or even relative disintegration). The extent of ethno-linguistic heterogeneity across regions and cities became a force making for asymmetric intra-empire market integration from the late 1880s, early 1890s onwards, roughly in line with the time pattern suggested by the historiography of rising national conflict across the empire. This, the analysis suggests, was the outcome of two factors, in particular. First, as markets became more closely integrated as a result of declining transport costs, the relative importance of other non-distance related barriers to inter-regional exchange, such as ethnic or linguistic differences, increased. Second, the absolute importance of these differences rose with increasingly ethnically-based forms of social and economic organisation such as trade co-operatives, especially from the mid-1880s. While the formation of ethno-linguistic networks entailed a lowering of 
information costs among members and helped diffuse common preferences, it also reduced the extent of effective exchange with non-network members. It has been shown here that it was not growing difficulties in communication between ethno-linguistic groups that led to growing price differentials between different markets, but rather intensifying conflict between them.

These findings tie in well with recent qualitative work on the prevalence of intra-state economic nationalism in Central and Eastern Europe. This literature suggests that ethnically-based networks increasingly affected trading costs between different ethnic groups by systematically directing trade towards the own group. ${ }^{52}$ Jaworski's research on boycott movements between different ethnic groups within the multi-national setting of East Central Europe points to ethnic mobilization as a key element of intra-state economic nationalism at work. Nationalist élites sought to mobilize popular political support for the national cause and to advance the economic interests of their clientele. If so, arbitrage trade between ethnic groups became increasingly limited and hence affected price dynamics in a similar way as other, e.g. distance related, trading costs. In his study of rural cooperatives in Galicia, Struve identifies a key feature that applies not only to the specific case he investigates but more broadly to the late nineteenth century nation-building efforts that evolved within the multi-ethnic Habsburg setting: '(...) different nation-building projects competed with one another'. ${ }^{53}$ This 'competition', the evidence suggests, acquired an increasingly exclusionary quality - Bruckmüller and Sandgruber's 'self-integrating national communities ${ }^{\prime 54}$ were indeed alive, ventured to keep 'others'

\footnotetext{
52 Jaworski, 'Zwischen ökonomischer Interessenvertretung'; Lorenz, ed., Cooperatives in Ethnic Conflicts.

${ }^{53}$ Struve, 'Peasant emancipation', p.229.

${ }^{54}$ Bruckmüller and Sandgruber, 'Concepts of economic integration'.
} 
out and so foreshadowed the break-up of the Habsburg Empire a generation later. 


\section{References}

Albrecht, C., 'Rural banks and Czech nationalism in Bohemia, 18481914', Agricultural History, 78 (3) (2004), pp. 317-45.

Anderson, J. and E. van Wincoop, 'Gravity with gravitas: a solution to the border puzzle', American Economic Review, 93 (1) (2003), pp. 170-92.

Berend, I.T., History derailed: Central and Eastern Europe in the long nineteenth century (Berkeley, CA, 2003).

Berend, I.T. and G. Ránki, 'Economic factors in nationalism: the example of Hungary at the beginning of the twentieth century', Austrian History Yearbook, 3 (1967), pp. 163-88.

Bruckmüller, E. and R. Sandgruber, 'Concepts of economic integration in Austria during the twentieth century', in A. Teichova and H. Matis, eds., Nation, state and the economy in history (Cambridge, 2003), pp. $159-80$.

Combes, P.-P., M. Lafourcade, and T. Mayer, 'The trade-creating effects of business and social networks: evidence from France', J ournal of International Economics, 66 (2005), pp. 1-29.

Dyen, I., J. Kruskal, and P. Black, 'An Indo-European classification: a lexicostatistical experiment', Transactions of the American Philosophical Society, New Series 82/ 5, (1992), pp. iii-132.

Eddie, S., 'Economic policy and economic development in AustriaHungary, 1867-1913', in P. Matthias and S. Pollard, eds., The Cambridge economic history of Europe, vol. VIII, (Cambridge, 1989) pp. 814-86.

Eddie, S., 'Financing the common expenditures of the dual monarchy', in K. Halmos et al., eds., A felhalmozás Míve. Történeti Tanulmányok Kövér György Tiszteletére (Budapest, 2009), pp. 35981.

Engel, C. and J. Rogers, 'How wide is the border?', American Economic Review, 86 (5), (1996) pp. 1112-25.

Fackler, P.L. and Goodwin, B.K., 'Spatial price analysis', in B.L. Gerdener and G.C. Rauser, eds., Handbook of Agricultural Economics, Vol. 1 (Amsterdam, 2001). 
Gerschenkron, A., Economic backwardness in historical perspective (Cambridge, MA, 1962).

Good, D.F., The economic rise of the Habsburg Empire, 1750-1918 (Berkeley, CA, 1984).

Gorkiewicz, M., 'Ceny w Krakowie w latach 1796-1914', Badania z Dziejow Spolecznych I Gospodarczych 16 (1950).

Greif, A., 'Contract enforceability and economic institution in early trade: the Maghribi traders coalition', American Economic Review 83 (3), (1993) pp. 525-48.

Horch, M., 'Language and identity', in R.L. Rudolph and D.F. Good (eds.), Nationalism and empire. The Habsburg Empire and the Soviet Union (New York 1992), pp. 65-76.

Hoszowski, S., 'Ceny we Iwowie w latach 1701-1914', Badania z Dziejow Spolecznych I Gospodarczych 13 (1934).

Jaworski, R., 'Zwischen ökonomischer Interessenvertretung und national-kultureller Selbstbehauptung. Zum Wirtschaftsnationalismus in Ostmitteleuropa vor 1914', Zeitschrift für OstmitteleuropaForschung, (2004), pp. 257-68.

Komlos, J., The Habsburg Monarchy as a customs union. Economic development in Austria-Hungary in the nineteenth century (Princeton, NJ, 1983).

Komlos, J., Stature, nutrition and economic development in the eighteenth century Habsburg Monarchy: The 'Austrian' model of the industrial revolution (Princeton, NJ, 1989).

Kornish, S.G., 'Constitutional aspects of the struggle between Germans and Czechs in the Austro-Hungarian Monarchy', Journal of Modern History, 21, (1949) pp. 231-61.

Lieven, D., The Russian Empire and its rivals (2000).

Lorenz, T. (ed.), Cooperatives in ethnic conflicts: eastern Europe in the 19th and early 20th century (Berlin, 2007).

Noyes, W.G., American railroad rates (Boston, 1905). 
Pogany, A, E. Kubu and J. Kofman, Für eine nationale Wirtschaft. Ungarn, die Tschechoslowakei und Polen vom Ausgang des 19.J ahrhunderts bis zum Zweiten Weltkrieg (Berlin, 2006).

Pribram, A.F., Materialien zur Geschichte der Löhne und Preise in Österreich, vol. I (Vienna, 1938).

Rauch, J., 'Business and social networks in international trade', J ournal of Economic Literature, 39, (2001), pp. 1177-203.

Rauch, J. and V. Trindade, 'Ethnic Chinese networks in international trade', Review of Economics and Statistics, 84 (1), (2002), pp. 11630.

Rudolph, R.L. and D.F. Good, eds., Nationalism and empire: the Habsburg Empire and the Soviet Union (New York, 1992).

Schulze, M.S., 'Patterns of growth and stagnation in the late nineteenth century Habsburg economy', European Review of Economic History, 4, (2000) pp. 311-40.

Schulze, M.S., 'Austria-Hungary's economy in World War I', in S. Broadberry and M. Harrison (eds.), The economics of World War I (Cambridge, 2005), pp.77-111.

Schulze, M.S., 'Origins of catch-up failure: comparative productivity growth in the Habsburg Empire, 1870-1910', European Review of Economic History, 11, (2007), pp. 189-218.

Schulze, M.S., 'Regional income dispersion and market potential in the late nineteenth century Habsburg Empire', London School of Economics, Working Papers in Economic History 106/07 (2007).

Shiue, C., 'From political fragmentation towards a customs union: border effects of the German Zollverein, 1815 to 1855', European Review of Economic History, 9, (2005) pp. 129-62.

Sked, A., The decline and fall of the Habsburg Empire, 1815-1918 (Harlow, 2001).

Struve, K., 'Peasant emancipation and national integration. Agrarian circles, village reading rooms, and cooperatives in Galicia', in T. Lorenz, ed., Cooperatives in ethnic conflicts: Eastern Europe in the 19th and early 20th century (Berlin, 2007). 
Taylor, A.J.P., The Habsburg Monarchy 1809-1918: A history of the Austrian Empire and Austria-Hungary (London, 1948).

Trenkler, C. and N. Wolf, 'Economic integration across borders: the Polish interwar economy 1921-1937', European Review of Economic History, 9, (2005), pp. 199-231.

(US) Bureau of Railway Economics, Comparison of railway freight rates in the United States (and) the principal countries of Europe, south Australia, and south Africa (Washington, D.C., 1915).

Wank, S., 'The Habsburg Empire', in K. Barkey and M. von Hagen (eds.), After empire. Multiethnic societies and nation-building. The Soviet Union and the Russian, Ottoman, and Habsburg Empires (Boulder, 1997).

Wank, S., 'Some reflections on the Habsburg Empire and its legacy in the nationalities question', Austrian History Yearbook 28, (1997) pp. $131-46$.

Wolf, H. (2000), 'Intra-national home bias in trade"' Review of Economics and Statistics, 82/4, (2000), pp. 555-563.

Wolf, N., 'Path dependent border effects: the case of Poland's reunification (1918-1939)', Explorations in Economic History, 42, (2005), pp. 414-38.

\section{Official Publications, Maps, Reports, Statistics}

Austria - Census (1880-1910): K.K. Statistische Central-Commission, 'Die Ergebnisse der Volkszählung vom 31. Dezember 1880 (1890, 1900, 1910)', Österreichische Statistik I (XXXII, LXIII, N.F. - I), (Vienna 1882, 1892-3, 1902-5, 1916-8).

Hungary - Census (1880-1910): Magyar Kir. Központi Statisztikai Hivatal, 'Népszámlálás $1891 \quad(1910)$ ', Magyar Statisztikai Közlemények U.F. - 1 (U.F. - 64), (Budapest 1893, 1915-6).

MSE: Magyar Kir. Központi Statisztikai Hivatal, Magyar Statisztikai Évkönyv, 1872-1915 (Budapest).

ÖSH: k.k. Statistische Central-Commission, Österreichisches Statistisches Handbuch, 1883-1915 (Vienna).

Preisstatistik (1913): Központi Statisztikai Hivatal, Preisstatistik (Budapest). 
Railway Distances (1878-1913):

(a) Eisenbahn-Karte von Oesterreich-Ungarn, bearb. von T. v. Bomsdorff, einschl. Kilometer-Zeiger fuer die Eisenbahnen Oesterreich-Ungarns (Vienna: 1878).

(b) Oesterreich-Ungarn. Eisenbahn-Karte, gezeichnet und bearbeitet von T. v. Bomsdorff (Vienna: 1883).

(c) Artaria's Eisenbahn-, Post- und Communicationskarte von Oesterreich-Ungarn (Vienna: 1888, 1891, 93, 1900).

(d) Eisenbahn- und Strassenkarte der oesterreichisch-ungarischen Monarchie (Vienna: 1904).

(e) Uebersichtskarte der Eisenbahnen der oesterreichischungarischen Monarchie (Vienna: 1913).

(f) Artaria's Eisenbahnkarte von Oesterreich-Ungarn, 3. Aufl., einschl. Stationsverzeichnis, etc. (Vienna: 1913).

(g) A. Bechtel, Kilometerzeiger zu den allgemeinen und MilitaerTarifen der oesterreichisch-ungarischen Eisenbahnen (Vienna: 188291).

(h) F. Smolik, Offizieller Kilometerzeiger der saemtlichen oesterreichisch-ungarischen und bosnisch-hercegovinischen Eisenbahnen (Vienna: 1912).

SJ B: k.k. Statistische Central-Commission, Statistisches J ahrbuch der österreichischen Monarchie, 1869-1882 (Vienna). 

Table 1. Main languages spoken (shares in total population)

\begin{tabular}{|c|c|c|c|c|c|c|c|c|c|c|c|c|c|c|c|c|c|c|}
\hline & \multicolumn{2}{|c|}{ German } & \multicolumn{2}{|c|}{ Czech/ Slovak } & \multicolumn{2}{|c|}{ Polish } & \multicolumn{2}{|c|}{ Ukrainian } & \multicolumn{2}{|c|}{ Slovene } & \multicolumn{2}{|c|}{ Serbo-Croat } & \multicolumn{2}{|l|}{ I talian } & \multicolumn{2}{|c|}{ Romanian } & \multicolumn{2}{|c|}{ Hungarian } \\
\hline & 1880 & 1910 & 1880 & 1910 & 1880 & 1910 & 1880 & 1910 & 1880 & 1910 & 1880 & 1910 & \begin{tabular}{|l|}
1880 \\
\end{tabular} & 1910 & 1880 & 1910 & 1880 & 1910 \\
\hline Vienna & 958 & 0.941 & 0.036 & .054 & 0.003 & 0.003 & 0.001 & 0.001 & 0.001 & 0.001 & 0.000 & 0.000 & $\mid 0.001$ & 0.001 & 0.000 & 0.000 & \begin{tabular}{|l|}
0.000 \\
\end{tabular} & .000 \\
\hline Linz & 84 & 995 & 015 & 004 & 0.000 & 0.000 & 0.000 & 0.000 & .000 & 0.000 & 0.000 & 0.000 & \begin{tabular}{|l|l|}
0.000 \\
\end{tabular} & 0.000 & 0.000 & 0.000 & 0.000 & 0.000 \\
\hline Graz & 982 & 0.991 & 0.009 & 0.001 & 0.000 & 0.000 & 0.000 & 0.000 & 0.008 & 0.006 & 0.000 & 0.000 & \begin{tabular}{|l|}
0.001 \\
\end{tabular} & 0.001 & 0.000 & 0.000 & 0.000 & 0.000 \\
\hline I nnsbruck & 985 & 0.976 & 0.002 & 0.002 & 0.000 & 0.001 & 0.000 & 0.002 & 0.000 & 0.002 & 0.000 & 0.000 & \begin{tabular}{|l|}
0.013 \\
\end{tabular} & 0.016 & 0.000 & 0.000 & $\mid 0.000$ & 0.000 \\
\hline Prag & 165 & 0.068 & 0.834 & .930 & 0.001 & 0.000 & .000 & 0.000 & 0.000 & 0.000 & 0.000 & 0.000 & $\mid 0.000$ & 0.000 & 0.000 & .000 & .000 & .000 \\
\hline Lemberg & 0.084 & 0.024 & 0.002 & 0.002 & 0.650 & 0.750 & 0.262 & 0.223 & 0.000 & 0.000 & 0.000 & 0.000 & $\mid 0.000$ & 0.000 & 0.001 & 0.000 & $\mid 0.000$ & 0.000 \\
\hline Cracow & 039 & 0.024 & 0.007 & 0.012 & 0.953 & 0.959 & 0.001 & 0.004 & 0.000 & 0.000 & 0.000 & 0.000 & \begin{tabular}{|l|}
0.000 \\
\end{tabular} & 0.000 & 0.000 & 0.000 & 0.000 & 0.000 \\
\hline Czernowitz & 266 & 0.288 & 0.004 & 0.003 & 0.071 & 0.098 & 0.479 & 0.383 & 0.000 & 0.000 & 0.000 & 0.000 & \begin{tabular}{|l|l|}
0.000 \\
\end{tabular} & 0.000 & 0.180 & 0.228 & $\mid 0.000$ & 0.000 \\
\hline Trieste & 0.043 & 0.062 & 0.001 & 0.003 & 0.000 & 0.001 & 0.000 & 0.000 & 0.218 & 0.298 & 0.001 & 0.013 & \begin{tabular}{|l|}
0.738 \\
\end{tabular} & 0.623 & 0.000 & 0.000 & \begin{tabular}{|l|}
0.000 \\
\end{tabular} & 0.000 \\
\hline Budapest & 0.212 & 0.084 & 0.065 & 0.029 & 0.006 & 0.006 & 0.000 & 0.000 & 0.000 & 0.000 & 0.010 & 0.005 & \begin{tabular}{|l|}
0.001 \\
\end{tabular} & 0.001 & 0.001 & 0.002 & 0.705 & 0.872 \\
\hline Pozsony & 183 & 0.137 & 0.456 & 0.434 & 0.002 & 0.002 & 0.000 & 0.000 & 0.000 & 0.000 & 0.007 & 0.005 & \begin{tabular}{|l|}
0.001 \\
\end{tabular} & 0.001 & 0.000 & 0.000 & 0.351 & 0.421 \\
\hline Pecs & 0.347 & 0.332 & 0.008 & 0.007 & 0.000 & 0.001 & 0.000 & 0.000 & 0.002 & 0.002 & 0.115 & 0.069 & $\mid 0.001$ & 0.001 & 0.002 & 0.000 & $|0.525|$ & 0.588 \\
\hline Sopron & 413 & 0.387 & 0.004 & 0.004 & 0.000 & 0.000 & 0.000 & 0.000 & 0.001 & 0.001 & 0.117 & 0.110 & \begin{tabular}{|l|} 
\\
\end{tabular} & 0.001 & 0.000 & 0.000 & \begin{tabular}{|l|}
0.464 \\
\end{tabular} & 0.497 \\
\hline Szeged & 0.012 & 0.009 & 0.004 & 0.002 & 0.001 & 0.000 & 0.000 & 0.000 & 0.000 & 0.000 & 0.002 & 0.004 & 0.001 & 0.000 & 0.001 & 0.001 & \begin{tabular}{|l|}
0.980 \\
\end{tabular} & 0.983 \\
\hline Kassa & 0.069 & 0.031 & 0.293 & 0.181 & 0.004 & 0.004 & 0.003 & 0.001 & 0.000 & 0.000 & 0.000 & 0.000 & \begin{tabular}{|l|}
0.000 \\
\end{tabular} & 0.000 & 0.000 & 0.000 & \begin{tabular}{|l|}
0.631 \\
\end{tabular} & 0.781 \\
\hline Debreczen & 0.017 & 0.004 & 0.003 & 0.001 & 0.000 & 0.000 & 0.000 & 0.000 & 0.000 & 0.000 & 0.000 & 0.000 & \begin{tabular}{|l|}
0.001 \\
\end{tabular} & 0.000 & 0.000 & .001 & $\mid 0.978$ & 0.994 \\
\hline Nagyvarad & 0.010 & 0.005 & 0.011 & 0.013 & 0.001 & 0.000 & 0.001 & 0.000 & 0.000 & 0.000 & 0.000 & 0.000 & 0.000 & 0.000 & 0.435 & 0.413 & \begin{tabular}{|l|}
0.542 \\
\end{tabular} & 0.568 \\
\hline Arad & 0.107 & 0.094 & 0.012 & 0.014 & 0.000 & 0.000 & 0.000 & 0.002 & 0.000 & 0.000 & 0.007 & 0.005 & \begin{tabular}{|l|}
0.001 \\
\end{tabular} & 0.000 & 0.639 & 0.584 & \begin{tabular}{|l|}
0.233 \\
\end{tabular} & 0.301 \\
\hline Temesvar & 0.350 & 0.328 & 0.016 & 0.012 & 0.001 & 0.000 & 0.000 & 0.000 & 0.000 & 0.000 & 0.141 & 0.133 & $\mid 0.000$ & 0.000 & 0.421 & 0.363 & $\mid 0.070$ & 0.164 \\
\hline Kolozs & 0.042 & 0.029 & 0.002 & 001 & 0.001 & 000 & 000 & .000 & 000 & 0.000 & 0.000 & 0.000 & 0.000 & 0.000 & .612 & 57. & .343 & 0.395 \\
\hline
\end{tabular}

Sources: Austria - Census (1880-1910); Hungary - Census (1880-1910) 

Table 2. Asymmetric integration - balanced sample, basic results, 1878-1910

\begin{tabular}{lll}
\hline \multicolumn{2}{c}{ Pooled EGLS } \\
\hline Variable & Coeff. (t-stat.) & Coeff. (t-stat.) \\
& & \\
Constant & $1.0629(14.896)$ & $0.9329(12.174)$ \\
log(raildistance) & $0.0096(0.848)$ & $0.0286(2.566)$ \\
log(freightcost) & & $-0.0797(-2.611)$ \\
language & $-0.0979(-3.148)$ & yes \\
fixed city effects & yes & 10,070 \\
no. of obs. & 10,070 & 0.8856 \\
adj. R ${ }^{2}$ (weighted) & 0.8848 &
\end{tabular}

dep. var. log price-ratio as defined in text; White period standard errors and covariance

Table 3. Asymmetric integration - balanced sample, time variation and city-specific shocks

\begin{tabular}{lll}
\hline \multicolumn{3}{c}{ Pooled EGLS } \\
\hline Variable & Coeff. (t-stat.) & Coeff. (t-stat.) \\
& & \\
constant & $0.7785(9.447)$ & $0.8134(9.510)$ \\
$D_{95-10}$ & $0.1324(9.998)$ & $-0.0289(-0.893)$ \\
log(freightcost) & $.0 .0445(3.829)$ & $0.0486(4.049)$ \\
language*D & $-0.0200(-0.550)$ & $0.0083(0.208)$ \\
language* & $-0.1545(-5.242)$ & $-0.1492(-4.062)$ \\
fixed city effects & yes & no \\
time-varying city effects & no & yes \\
no. of obs. & 10,070 & 10,070 \\
adj. R ${ }^{2}$ (weighted) & 0.8488 & 0.8589 \\
& & \\
\hline
\end{tabular}

dep. var. log price-ratio as defined in text; White period standard errors and covariance 
Table 4. Communty vs. communication effects, balanced sample

\begin{tabular}{|c|c|c|}
\hline \multicolumn{3}{|c|}{ Pooled EGLS } \\
\hline \multicolumn{2}{|c|}{ communication } & $\begin{array}{l}\text { community } \\
\text { (Herfindahl) }\end{array}$ \\
\hline Variable & Coeff. (t-stat.) & Coeff. (t-stat.) \\
\hline constant & $0.8137(9.742)$ & $0.8115(9.473)$ \\
\hline$D_{95-10}$ & $-0.0477(-1.411)$ & $-0.1624(-3.108)$ \\
\hline $\log$ (freightcost) & $0.0486(4.127)$ & $0.0494(4.186)$ \\
\hline language $* D_{78-94}$ & $0.0189(0.170)$ & \\
\hline language $* D_{95-10}$ & $-0.4160(-4.074)$ & \\
\hline dyencomm $* D_{78-94}$ & $-0.0093(-0.099)$ & $-0.0002(-0.002)$ \\
\hline dyencomm* $D_{95-10}$ & $0.2643(3.185)$ & $0.2373(3.147)$ \\
\hline \multirow{2}{*}{\multicolumn{2}{|c|}{$\begin{array}{l}\text { hflang* } D_{78-94} \\
\text { hflang*D } D_{95-10}\end{array}$}} & $-0.0097(-0.084)$ \\
\hline & & $0.3862(4.086)$ \\
\hline $\begin{array}{l}\text { hflang* } D_{95-10} \\
\text { time-varving citv effects }\end{array}$ & yes & yes \\
\hline \multirow{2}{*}{\multicolumn{2}{|c|}{$\begin{array}{l}\text { no. of obs. } \\
\text { adi. } R^{2} \text { (weiahted) }\end{array}$}} & 10,070 \\
\hline & & 0.8618 \\
\hline
\end{tabular}

dep. var. log price-ratio as defined in text; White period standard errors and covariance

Table 5. Pre-war integration and post-war boundaries

\begin{tabular}{llc}
\hline \multicolumn{3}{c}{ Binary Probit } \\
Variable & $\begin{array}{l}\text { two grains } \\
\text { Coeff. (z-stat.) }\end{array}$ & $\begin{array}{l}\text { five grains } \\
\text { Coeff. (z-stat.) }\end{array}$ \\
& & \\
constant & $0.5160(3.104)$ & $0.3785(1.630)$ \\
spreadchange & $4.2283(3.948)$ & $5.0359(3.085)$ \\
& & \\
log-likelihood & -76.9857 & -31.6387 \\
restr. log-likelihood & 82.8708 & -36.5087 \\
LR statistic & 11.7703 & 9.7400 \\
probability (LR stat) & 0.0006 & 0.0018 \\
no. of obs. & 190 & 77 \\
McFadden R & 0.0710 & 0.1334 \\
& &
\end{tabular}

dep. var. border as defined in text; Huber/White standard errors and covariance 
Figure 1. Total freight cost per ton of grain (old pence), selected distances, 1870-1910

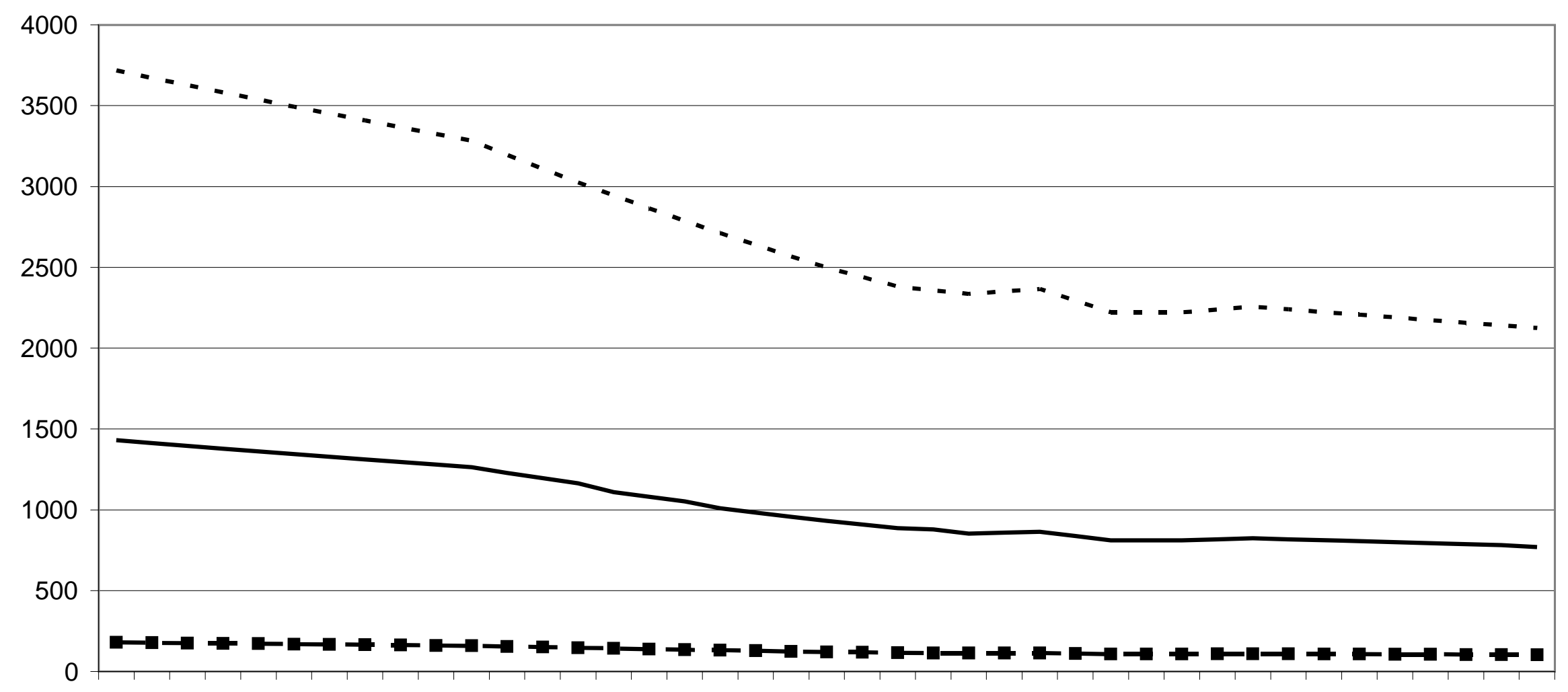

187018721874187618781880188218841886188818901892189418961898190019021904190619081910

$\longrightarrow$ median $\rightarrow-$ shortest (Arad Temesvar) - - - longest (Innsbruck Czernowitz) 


\section{Figure 2. Cross-section average prices, five grains, 1878-1910 (heller per $100 \mathrm{~kg}$ )}

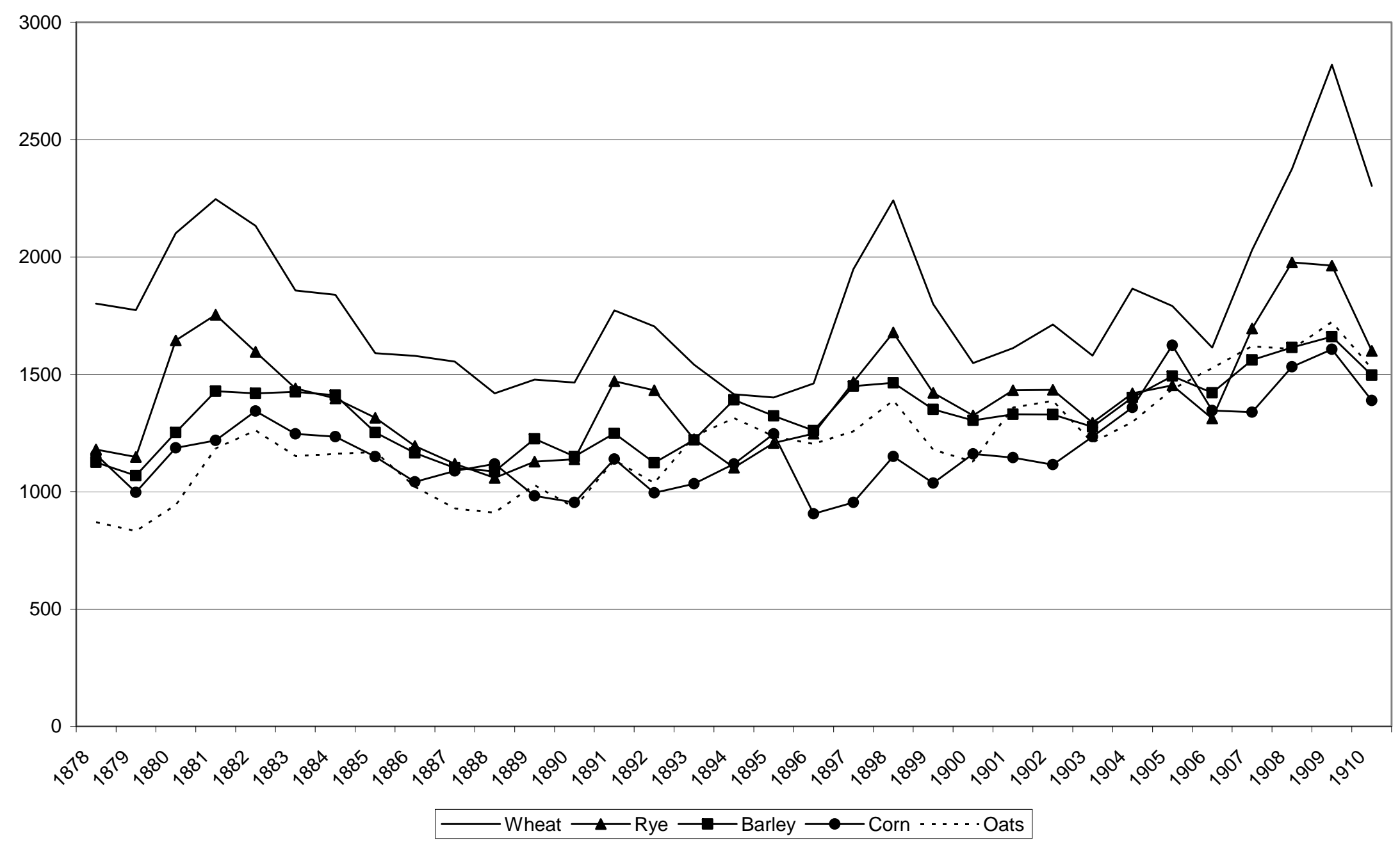


Figure 3: Coefficient of Variation

within and between Ethno-linguistic Groups

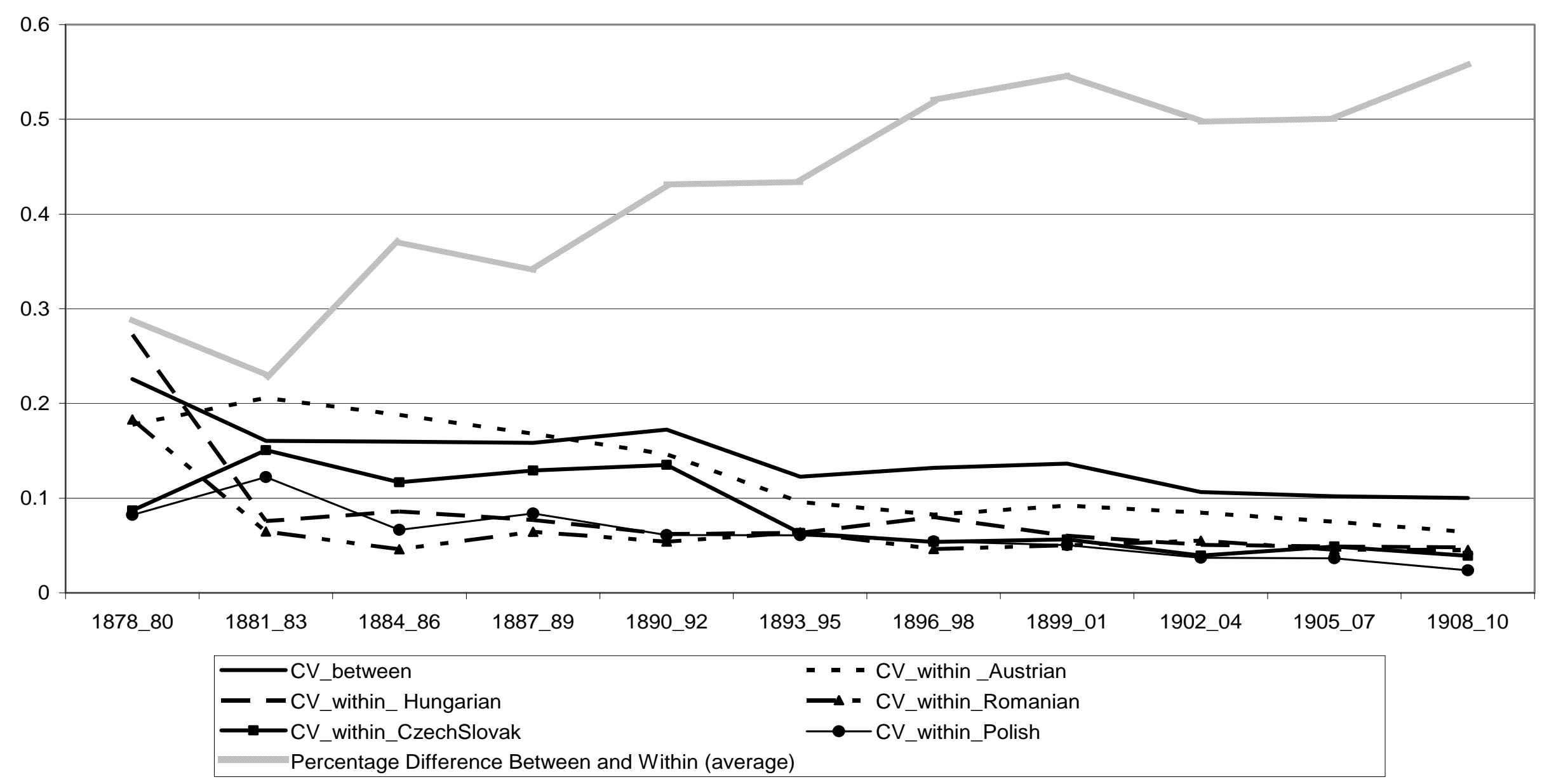


Map 1. The Habsburg Empire in 1914 borders, main cities and post-1918 political borders

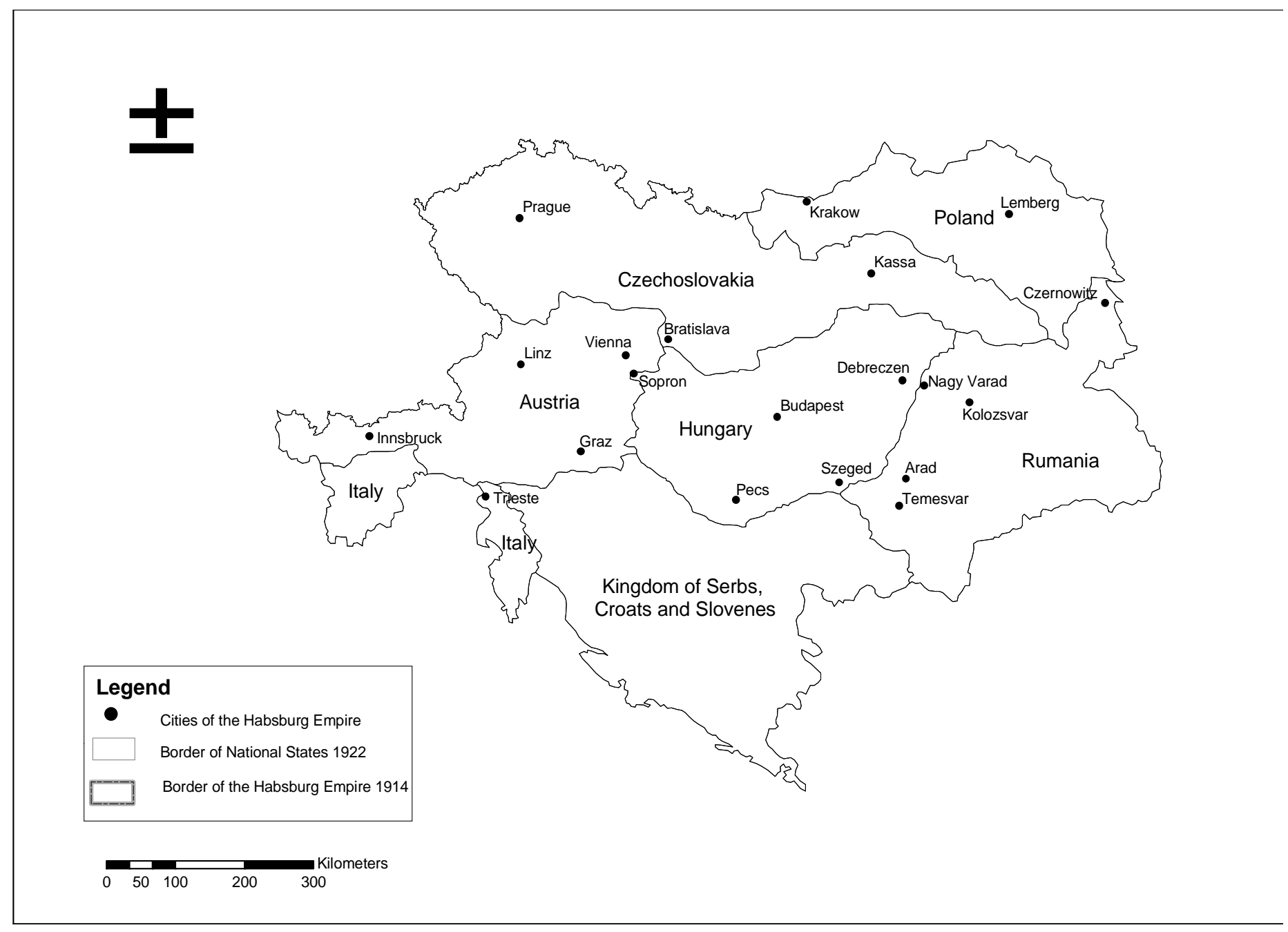




\section{CESifo Working Paper Series}

for full list see www.cesifo-group.org/wp

(address: Poschingerstr. 5, 81679 Munich, Germany, office@cesifo.de)

2749 Rüdiger Pethig and Christian Wittlich, Interaction of Carbon Reduction and Green Energy Promotion in a Small Fossil-Fuel Importing Economy, August 2009

2750 Kai Carstensen, Oliver Hülsewig and Timo Wollmershäuser, Monetary Policy Transmission and House Prices: European Cross-country Evidence, August 2009

2751 Olaf Posch, Explaining Output Volatility: The Case of Taxation, August 2009

2752 Beatrice Scheubel, Daniel Schunk and Joachim Winter, Don't Raise the Retirement Age! An Experiment on Opposition to Pension Reforms and East-West Differences in Germany, August 2009

2753 Daniel G. Arce, Dan Kovenock and Brian Roberson, Suicide Terrorism and the Weakest Link, August 2009

2754 Mario Larch and Wolfgang Lechthaler, Comparative Advantage and Skill-Specific Unemployment, August 2009

2755 Horst Raff and Nicolas Schmitt, Buyer Power in International Markets, August 2009

2756 Seppo Kari, Hanna Karikallio and Jukka Pirttilä, The Impact of Dividend Taxation on Dividends and Investment: New Evidence Based on a Natural Experiment, August 2009

2757 Mirco Tonin and Michael Vlassopoulos, Disentangling the Sources of Pro-social Behavior in the Workplace: A Field Experiment, August 2009

2758 Nicole Grunewald and Inmaculada Martínez-Zarzoso, Driving Factors of Carbon Dioxide Emissions and the Impact from Kyoto Protocol, August 2009

2759 Yu-Fu Chen and Michael Funke, Booms, Recessions and Financial Turmoil: A Fresh Look at Investment Decisions under Cyclical Uncertainty, August 2009

2760 Jan-Egbert Sturm and Jakob de Haan, Does Central Bank Communication really Lead to better Forecasts of Policy Decisions? New Evidence Based on a Taylor Rule Model for the ECB, August 2009

2761 Larry Karp, Sacrifice, Discounting and Climate Policy: Five Questions, August 2009

2762 Marianna Belloc and Samuel Bowles, International Trade, Factor Mobility and the Persistence of Cultural-Institutional Diversity, August 2009

2763 Charles Noussair and Fangfang Tan, Voting on Punishment Systems within a Heterogeneous Group, August 2009 
2764 Birgit Bednar-Friedl and Karl Farmer, Internationally Coordinated Emission Permit Policies: An Option for Withdrawers from the Kyoto Protocol?, August 2009

2765 Pierre M. Picard and David E. Wildasin, Labor Market Pooling, Outsourcing and Labor Contracts, August 2009

2766 Stefan Voigt and Lorenz Blume, The Economic Effects of Federalism and Decentralization - A Cross-Country Assessment, August 2009

2767 David S. Jacks, Christopher M. Meissner and Dennis Novy, Trade Booms, Trade Busts, and Trade Costs, August 2009

2768 Mario Jametti and Thomas von Ungern-Sternberg, Hurricane Insurance in Florida, August 2009

2769 Alessandro Balestrino, Kind of Black: The Musicians' Labour Market in Italy, August 2009

2770 Yosr Abid Fourati and Cathal O’Donoghue, Eliciting Individual Preferences for Pension Reform, August 2009

2771 Christian Breuer and Chang Woon Nam, VAT on Intra-Community Trade and Bilateral Micro Revenue Clearing in the EU, August 2009

2772 Choudhry Tanveer Shehzad, Jakob De Haan and Bert Scholtens, Growth and Earnings Persistence in Banking Firms: A Dynamic Panel Investigation, August 2009

2773 Erdal Yalcin, Uncertain Productivity Growth and the Choice between FDI and Export, August 2009

2774 Klaus Abberger, Wolfgang Nierhaus and Shynar Shaikh, Findings of the Signal Approach for Financial Monitoring in Kazakhstan, September 2009

2775 Sascha O. Becker, Francesco Cinnirella and Ludger Woessmann, The Trade-off between Fertility and Education: Evidence from before the Demographic Transition, September 2009

2776 Thomas Aronsson and Erkki Koskela, Optimal Income Taxation, Outsourcing and Policy Cooperation in a Dynamic Economy, September 2009

2777 Joel Slemrod, Old George Orwell Got it Backward: Some Thoughts on Behavioral Tax Economics, September 2009

2778 Cagri Seda Kumru and Athanasios C. Thanopoulos, Social Security Reform and Temptation, September 2009

2779 Alessandro Bucciol and Roel M. W. J. Beetsma, Inter- and Intra-generational Consequences of Pension Buffer Policy under Demographic, Financial and Economic Shocks, September 2009 
2780 Eduardo Strube and Marcelo Resende, Complementarity of Innovation Policies in the Brazilian Industry: An Econometric Study, September 2009

2781 Henry Tulkens and Vincent van Steenberghe, "Mitigation, Adaptation, Suffering": In Search of the Right Mix in the Face of Climate Change, September 2009

2782 Maria L. Loureiro, Anna Sanz-de-Galdeano and Daniela Vuri, Smoking Habits: Like Father, Like Son, Like Mother, Like Daughter, September 2009

2783 Momi Dahan, Tehila Kogut and Moshe Shalem, Do Economic Policymakers Practice what they Preach? The Case of Pension Decisions, September 2009

2784 Eytan Sheshinski, Uncertain Longevity and Investment in Education, September 2009

2785 Nannette Lindenberg and Frank Westermann, How Strong is the Case for Dollarization in Costa Rica? A Note on the Business Cycle Comovements with the United States, September 2009

2786 Leif Danziger, Noncompliance and the Effects of the Minimum Wage on Hours and Welfare in Competitive Labor Markets, September 2009

2787 Gerlinde Fellner, Rupert Sausgruber and Christian Traxler, Testing Enforcement Strategies in the Field: Legal Threat, Moral Appeal and Social Information, September 2009

2788 Gabriel J. Felbermayr, Mario Larch and Wolfgang Lechthaler, Unemployment in an Interdependent World, September 2009

2789 Sebastian G. Kessing, Federalism and Accountability with Distorted Election Choices, September 2009

2790 Daniel Gros, Global Welfare Implications of Carbon Border Taxes, September 2009

2791 Louis N. Christofides, Michael Hoy and Ling Yang, The Gender Imbalance in Participation in Canadian Universities (1977-2005), September 2009

2792 Jan K. Brueckner and Robert W. Helsley, Sprawl and Blight, September 2009

2793 Vidar Christiansen and Stephen Smith, Externality-correcting Taxes and Regulation, September 2009

2794 John Beirne, Guglielmo Maria Caporale, Marianne Schulze-Ghattas and Nicola Spagnolo, Global and Regional Spillovers in Emerging Stock Markets: A Multivariate GARCH-in-mean Analysis, September 2009

2795 Rüdiger Pethig and Frieder Kolleß, Asymmetric Capital-Tax Competition, Unemployment and Losses from Capital Market Integration, September 2009

2796 Ngo Van Long, Horst Raff and Frank Stähler, Innovation and Trade with Heterogeneous Firms, September 2009 
2797 Margit Osterloh and Bruno S. Frey, Research Governance in Academia: Are there Alternatives to Academic Rankings?, September 2009

2798 Thiess Buettner and Clemens Fuest, The Role of the Corporate Income Tax as an Automatic Stabilizer, September 2009

2799 Annette Alstadsæter, Measuring the Consumption Value of Higher Education, September 2009

2800 Peter Friedrich, Chang Woon Nam and Janno Reiljan, Local Fiscal Equalization in Estonia: Is a Reform Necessary?, September 2009

2801 Evžen Kočenda and Jan Hanousek, State Ownership and Control in the Czech Republic, September 2009

2802 Michael Stimmelmayr, Wage Inequality in Germany: Disentangling Demand and Supply Effects, September 2009

2803 Biswa N. Bhattacharyay, Towards a Macroprudential Surveillance and Remedial Policy Formulation System for Monitoring Financial Crisis, September 2009

2804 Margarita Katsimi, Sarantis Kalyvitis and Thomas Moutos, "Unwarranted" Wage Changes and the Return on Capital, September 2009

2805 Christian Lessmann and Gunther Markwardt, Aid, Growth and Devolution, September 2009

2806 Bas Jacobs and Dirk Schindler, On the Desirability of Taxing Capital Income to Reduce Moral Hazard in Social Insurance, September 2009

2807 Hans Gersbach and Noemi Hummel, Climate Policy and Development, September 2009

2808 David E. Wildasin, Fiscal Competition for Imperfectly-Mobile Labor and Capital: A Comparative Dynamic Analysis, September 2009

2809 Johan Eyckmans and Cathrine Hagem, The European Union's Potential for Strategic Emissions Trading through Minimal Permit Sale Contracts, September 2009

2810 Ruediger Bachmann and Christian Bayer, The Cross-section of Firms over the Business Cycle: New Facts and a DSGE Exploration, October 2009

2811 Slobodan Djajić and Michael S. Michael, Temporary Migration Policies and Welfare of the Host and Source Countries: A Game-Theoretic Approach, October 2009

2812 Devis Geron, Social Security Incidence under Uncertainty Assessing Italian Reforms, October 2009

2813 Max-Stephan Schulze and Nikolaus Wolf, Economic Nationalism and Economic Integration: The Austro-Hungarian Empire in the Late Nineteenth Century, October 2009 